\title{
Spatial Analysis to Determine Groundwater Recharge Area in Purworejo Regency, Central Java Province/Indonesia
}

\author{
Thomas Triadi Putranto ${ }^{1,2 *}$, and Daniel Eko Aryanto ${ }^{2}$ \\ ${ }^{1}$ Geological Engineering Department, Engineering Faculty, Diponegoro University, Semarang-Indonesia \\ ${ }^{2}$ Master Program of Environmental Science, School of Postgraduate Studies, Diponegoro University, Semarang-Indonesia
}

\begin{abstract}
The impact of land use change will lead to a reduction of the land that is supposed to be for the groundwater recharge area. The area which is previously as a protected area, becoming a cultivated area. Determination of groundwater recharge areas is needed to ensure the availability of groundwater in Purworejo regency. The objective of this study is at determining the suitability of land use for groundwater recharge areas. The method was developed by using spatial analysis tool based on rating and weighting value of some parameters, i.e. rock permeability, rainfall, land use, soil type, slope, and depth of groundwater depth. Results conduct that the groundwater recharge area covers around 42,192 ha. Most of the groundwater recharge areas are located in the protected area, but there are several occupied by cultivated areas.
\end{abstract}

Keywords: Spatial analysis; Recharge area; Groundwater; Purworejo regency.

\section{Introducing}

Space is the place that includes land space, sea space, and airspace, including space in the earth as a unity of territory, where humans and other living creatures, perform activities and maintain its survival. Space utilisation is an effort to realise space structure and spatial pattern by the spatial plan through the preparation and implementation of the program and its financing [1].

In general, the spatial plan of an area is more likely to consider the economic values than the environmental values. As a result of these trends, much of the land that should be a protected area (including groundwater recharge areas), is not functioning correctly. Sometimes even diverted its function into industrial areas, settlements, trade, offices, and others [2]. Therefore, the expected sustainable spatial planning should consider the limitations of the quantity and quality of water resources. As economic entities, water resources must be managed as economic goods through the principles of sustainable resource management [3].

Groundwater recharge refers to the entry of water from the unsaturated zone into the saturated zone below the water table surface, together with the associated flow away from the water table within the saturated zone [2]. Recharge occurs when water flows past the groundwater level and infiltrates into the saturated zone. It is an essential water component of the circulation cycle in nature [4].

Sustainable groundwater management is essential for the conservation of groundwater in groundwater discharge areas. Purworejo Regency argued notably in how they express sustainable energy and low-carbon goals. The growth of development in Purworejo Regency has contributed to the conversion of land which resulted in the reduction of the area for groundwater infiltration. The reduced groundwater recharge area causes groundwater filling to be disrupted and results in a decrease in groundwater availability [5]. This decrease in groundwater availability can disrupt the development process and the social problems of the community [5].

Land use is characterized by the arrangements, activities and inputs people undertake in a specific land cover type to produce, change or maintain it. It is a series of operations on land, carried out by man, with the intention to obtain products and/or benefits from using land resources [6].

Land use change is defined as a change in a type of land use to other uses. Land conversion may be permanently and may also be temporary. If the agricultural irrigated agricultural land is transformed into housing or industry, then the transfer of this land function is permanent. Land conversion is a mechanism that brings demand and supply to land and produces new land with different production system characteristics. The phenomenon of land conversion is part of the journey of transformation of the national economic structure [7].

The Remote Sensing and GIS tools have opened new paths in water resources studies. Remote sensing provides multi-spectral, multi-temporal and multi-sensor data of the earth's surface. One of the most considerable advantages of using remote sensing and GIS for hydrological investigations and monitoring is its ability to generate information in the spatial and temporal

\footnotetext{
* Corresponding author: putranto@ft.undip.ac.id
} 
domain which is very crucial for successful analysis, prediction and validation [8]. With the development of remote-sensing technology and its spatially accurate performance in georeference processes, the factors influential to groundwater prospect zonation can be more easily identified on a broad scale [9].

Geospatial technologies have become a vital tool in water studies due to their capability in developing spatiotemporal information and effectiveness in spatial data analysis and prediction [10]. Various studies have been carried out throughout the world to identify the groundwater recharge potential zones by employing remote sensing and GIS techniques [11-15].

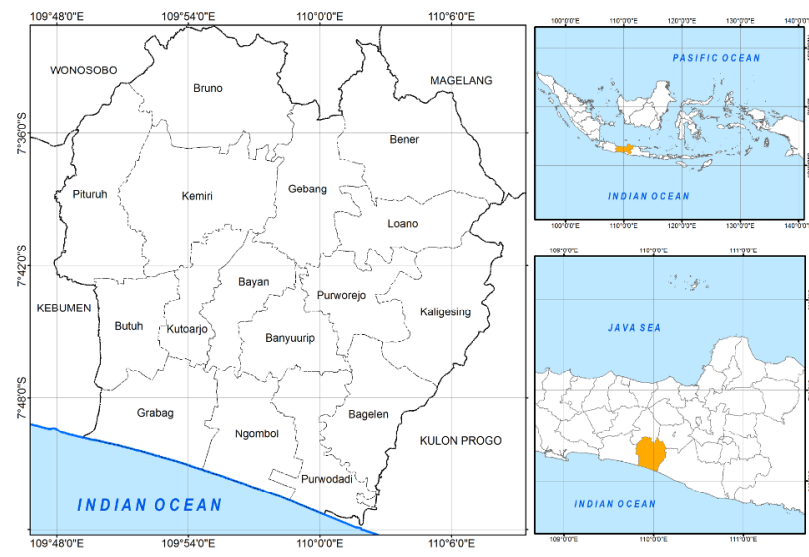

Fig. 1. Location map of the study area, Purworejo Regency, Central Java Province, Indonesia

\section{Study Area}

Geographically Purworejo Regency is located on the coast of the Indian Ocean, in the southern part of Java Island at coordinates $7^{\circ} 32^{\prime}$ to $7^{\circ} 54^{\prime}$ South Latitue and $109^{\circ} 47^{\prime} 28$ " to $110^{\circ} 8^{\prime} 20^{\prime \prime}$ East Longitude (Fig. 1). The astronomical position indicates that Purworejo District lies in a wet tropical climate with average rainfall in the range 2,326-4,077 $\mathrm{mm} / \mathrm{yr}$ and temperature between 19 $28^{\circ} \mathrm{C}$ while humidity in the range $70-90 \%$ [16].

Purworejo regency consists of 16 sub-districts namely District: Grabag, Ngombol, Purwodadi, Bagelen, Banyuurip, Bayan, Kutoarjo, Butuh, Pituruh, Kemiri, Bruno, Gebang, Purworejo, Kaligesing, Loano and Bener; and also consists of 496 villages.

Purworejo regency is locaced on the PurworejoKebumen Grondwater Basin based on Presidential Decree Number 26 Year 2011 with Longitude Coordinate: $109^{\circ} 27$ '18.50 "- $110^{\circ} 03^{\prime} \quad 36.50^{\prime \prime}$ and latitude Coordinates: $-07^{\circ} 34$ '14.61 "- $-07^{\circ} 53^{\prime}$ 59.96" [17].

\section{Methodology}

\subsection{Collecting Data}

A field campaign conducted primary data collection by a hydrogeological mapping. Measuring the water table of an unconfined aquifer, collecting water sample to analyse electrical conductivity value and $\mathrm{pH}$, as well as rock type data, were the main activities in the hydrogeological mapping.

Secondary data is obtained by a survey to the Regional Public Works Office of Purworejo Regency, and the Energy and Mineral Resources Agency in Central Java Province. Secondary data were used such as rainfall data from 2013 to 2017, soil type, land use, slope, and regional geological and hydrogeological map data.

\subsection{Data Analysis}

Geographic Information System (GIS) and data scoring to identify the potential groundwater recharge area were used in spatial data analysis. The analysis was then continued to assess the Spatial Planning of Purworejo regency based on the result of the groundwater recharge area.

\subsection{Weighting}

Determination of the groundwater recharge area map was developed by using weighting method and parameter scoring based on previously applied [18] with the modification of parameter classification, i.e. rock permeability, rainfall, land use, soil cover, slope and groundwater depth. Each parameter influences for developing groundwater recharge was differentiated by the weight value as shown in Table 1 . The parameter that has the highest weight was the ability of infiltration of groundwater while the lowest was groundwater depth.

Table 1. The Value of Weight of Groundwater Recharge Parameters (modified [18])

\begin{tabular}{lcl}
\hline Parameters & $\begin{array}{c}\text { Weight } \\
\text { Value }\end{array}$ & Information \\
\hline Rocks permeability & 6 & Very high \\
Rainfall & 5 & High \\
Land use & 4 & Enough \\
Type of soil & 3 & Medium \\
Slope & 2 & Low \\
Groundwater depth & 1 & Very low \\
& &
\end{tabular}

The details class of each parameter were listed in Table 2 .

According to [18], for defining the groundwater recharge area was carried out in the following stages:

1) Provide weight value of each parameter.

2) Specify the class rating of each parameter.

3) Summing the results of the multiplication between weight and rating values on each parameter.

4) Classify the groundwater recharge area based on the value of recharge, which is summing the multiplication between weight and rating values on each parameter with the formula in the equation 1. 
Table 2. Grade Rating and Weight of Rock permeability (modified after [18-21])

\begin{tabular}{|c|c|c|c|c|}
\hline Parameters & Rank & Class & Rating & Weight \\
\hline \multirow{5}{*}{$\begin{array}{l}\text { Rocks } \\
\text { permeability } \\
\text { (m/day) }\end{array}$} & Very high & $>10^{3}$ & 5 & 6 \\
\hline & High & $10^{1}-10^{3}$ & 4 & 6 \\
\hline & Moderate & $10^{-2}-10^{1}$ & 3 & 6 \\
\hline & Low & $10^{-4}-10^{-2}$ & 2 & 6 \\
\hline & Very Low & $<10^{-4}$ & 1 & 6 \\
\hline \multirow{5}{*}{$\begin{array}{l}\text { Rainfall } \\
(\mathrm{mm} / \mathrm{yr})\end{array}$} & Very high & $>4,000$ & 5 & 5 \\
\hline & High & $3,000-4,000$ & 4 & 5 \\
\hline & Moderate & $2,000-3,000$ & 3 & 5 \\
\hline & Low & $1,000-2,000$ & 2 & 5 \\
\hline & Very Low & $<1,000$ & 1 & 5 \\
\hline \multirow[t]{5}{*}{ Land Use } & Very high & Forest & 5 & 4 \\
\hline & High & Garden & 4 & 4 \\
\hline & Moderate & Shrubs & 3 & 4 \\
\hline & Low & $\begin{array}{l}\text { Empty land, } \\
\text { Vacant land, }\end{array}$ & 2 & 4 \\
\hline & Very Low & $\begin{array}{l}\text { Settlement, } \\
\text { Swamp, Rice } \\
\text { field }\end{array}$ & 1 & 4 \\
\hline \multirow[t]{5}{*}{ Soil type } & Very high & Regosol & 5 & 3 \\
\hline & High & Alluvial & 4 & 3 \\
\hline & Moderate & Lithosol & 3 & 3 \\
\hline & Low & Latosol & 2 & 3 \\
\hline & Very Low & Grumusol & 1 & 3 \\
\hline \multirow[t]{5}{*}{ Slope } & Very high & $>40^{\circ}$ & 5 & 2 \\
\hline & High & $20^{\circ}-40^{\circ}$ & 4 & 2 \\
\hline & Moderate & $10^{\circ}-20^{\circ}$ & 3 & 2 \\
\hline & Low & $5^{\circ}-10^{\circ}$ & 2 & 2 \\
\hline & Very Low & $<5^{\circ}$ & 1 & 2 \\
\hline \multirow{5}{*}{$\begin{array}{l}\text { Groundwater } \\
\text { depth } \\
\text { (unconfined } \\
\text { aquifer) }\end{array}$} & Very high & $>10$ & 5 & 1 \\
\hline & High & $7.5-10$ & 4 & 1 \\
\hline & Moderate & $5-7.5$ & 3 & 1 \\
\hline & Low & $2.5-5$ & 2 & 1 \\
\hline & Very Low & $<2.5$ & 1 & 1 \\
\hline
\end{tabular}

Recharge Value $=(\mathrm{Kb} \times \mathrm{Kp})+(\mathrm{Cb} \times \mathrm{Cp})+(\mathrm{Pb} \times \mathrm{Pp})+$ $(\mathrm{Tb} \times \mathrm{Tp})+(\mathrm{Lb} \times \mathrm{Lp})+(\mathrm{Mb} \times \mathrm{Mp})$

Information:

$\mathrm{K}$ : Rocks permeability

C : Rainfall

$\mathrm{P} \quad$ : Land Use

$\mathrm{T} \quad$ : Type of soil

L : Slope

M : Groundwater depth is not depressed

b : Weight Value

p : Rating Value

Classification of total value for defining groundwater recharge area was shown in Table 3.

Table 3. Classification of Weighted Value Results

\begin{tabular}{ccc}
\hline No. & $\begin{array}{c}\text { Potential Class of Water } \\
\text { Infiltration }\end{array}$ & Information \\
\hline 1 & $40-59$ & Discharge Area \\
2 & $60-76$ & Recharge Area \\
\hline
\end{tabular}

After obtaining the map of recharge and discharge areas of groundwater in Purworejo regency, the analysis was then continued by overlying the map to the spatial planning map of Purworejo regency in the year 20102030 for assessing recommendation of the function of the spatial area.

\section{Result and Discussion}

\subsection{Determination of Groundwater Recharge area}

The groundwater recharge area is obtained through spatial analysis of several parameters that influence the groundwater infiltration, i.e. Rocks permeability, Rainfall, Land Use, Type of soil, Slope, and Groundwater depth of the unconfined aquifer. The final result of the weighting of the geospatial analysis shows the location of the groundwater recharge area.

\subsubsection{Rocks permeability}

Parameter coefficient of permeability is the highest value for assessing groundwater recharge with weight 6 . The coefficient of permeability is associated with how easily a liquid move through a permeable layer. The fracture systems such as joins, dykes and porosity have influenced the capacity and specific storage of groundwater among the various rock types [22]. Rocks permeability is obtained from the type of rocks in the study site. The types of rocks in the study sites are breccia, sandstone, andesite rock, limestone, marl and tuff. According to [23], breccia rocks have a hydraulic conductivity value of $270 \mathrm{~m} /$ day; sandstone is around $3.1 \mathrm{~m} /$ day; limestone and andesite are $0.94 \mathrm{~m} /$ day and $0.0002 \mathrm{~m} /$ day, respectively.

From the mapping, the coefficient of permeability is around $10^{1}-10^{3} \mathrm{~m} /$ day spread over an area of $14,064.78$ ha; Rocks permeability $10^{-2}-10^{1} \mathrm{~m} /$ day covers 726,5072 ha. The rocks permeability which is around $10^{-4}-10^{-2}$ covering $65,797.59$ ha while less than $10^{-4}$ spreads over $27,391.67$ ha. Thus, the rating of rock permeability is ranging from 1 to 5 . The highest rating indicates the highest level of rock permeability.

\subsubsection{Rainfall}

The parameter of rainfall becomes the next most influential factor with the weight 5 . The higher the rainfall rate in a region, the possibility to infiltrate into the ground is getting higher. The number of rain stations taken in the study area is 27 sites. In the study area, the rainfall $<3,000 \mathrm{~mm} /$ year area occurs in an area of $60,531.16 \mathrm{ha}$; rainfall rate is in the range $3,000-4,000 \mathrm{~mm} /$ year covers $35,759.02 \mathrm{ha}$; and rainfall more than $4,000 \mathrm{~mm} /$ year spreads around $11,690.5$ ha. The highest rainfall rate indicates the highest rating to determine the groundwater recharge area

\subsubsection{Land Use}


Land use becomes the next determining factor for groundwater infiltration. The settlements area will be difficult for groundwater to infiltrate into the soil, and vice versa for land use forest, it will more easily infiltrate water into the soil.

The centre areas are dominantly by rice field and housing while the forest, garden, brush and empty land are located to the north. In the south, which is located the nearby the Indian Ocean, is mainly dominated by swamp, garden and rarely housing.

\subsubsection{Type of soil}

On the type of soil map at the study site consists of 4 types, namely regosol, latosol, latosol and alluvial soils. Alluvial and latosol have a better ability to absorb groundwater than regosol. The total area of regosol is $5,433,598$ ha while alluvial is up to $29,466.75$ ha and Latosol is around 10,235.91 ha.

\subsubsection{Slope}

The slope is a factor that affects the water infiltration, the higher the level of the slope, then the potential to absorb water is more significant. The slope of the research area shows that the flat areas are located in the south and the centre while the gentle to steep slopes are mainly in the north. These areas have a range of slope from $10^{\circ}$ to above $40^{\circ}$.

\subsubsection{Groundwater depth}

The survey point of groundwater level of the unconfined aquifer was performed on 64 sample points. The groundwater depth of the unconfined aquifer is ranging from 1 to 15 meters. It is classified into 5 categories that comprises a depth of $<2.5$ meters covering $35,316.69$ ha; 2.5 - 5 meters covering 38,026.77 ha; depth 5 - 7,5 meters covering $27,673.8$ ha; depth of 7.5 - 10 meters covering 6,616.138 ha; and depth $>10$ meters area of 347,278 ha.

\subsubsection{Recharge and Discharge Area of Groundwater}

The result of a map of recharge and discharge areas based on the six parameters performed by weighting using spatial analysis (Fig. 2). The recharge areas are spreading in the northern area which is in a hilly area with an area of 42,192.14 hectares and a groundwater discharge area spread over an area of $65,788.53$ ha in the centre and the south.

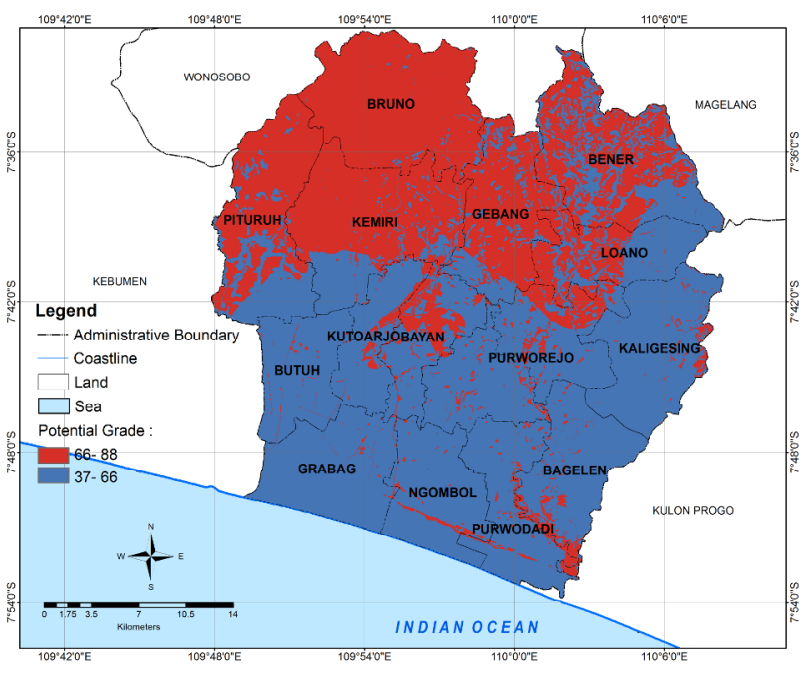

Fig. 2. Recharge and Discharge Area

\subsection{Suitability with Spatial Planning Map}

The groundwater recharge area that has been obtained, it was then overlaid to the Spatial Planning map of Purworejo Regency to highlight the level of compliance with the use of the area. From the result of the spatial analysis of groundwater recharge potential areas, it is found that most of the groundwater recharge areas are located in the protected area (Fig. 3). However, there are several uses of the cultivated area located in the groundwater recharge area.

Groundwater recharge areas which are converted as cultivation areas include production forest around 6,587.746 ha, dryland farming area of 7,781.1 ha, wetland farming area of $3,338.387$ ha, and settlement area of 627.351 ha.

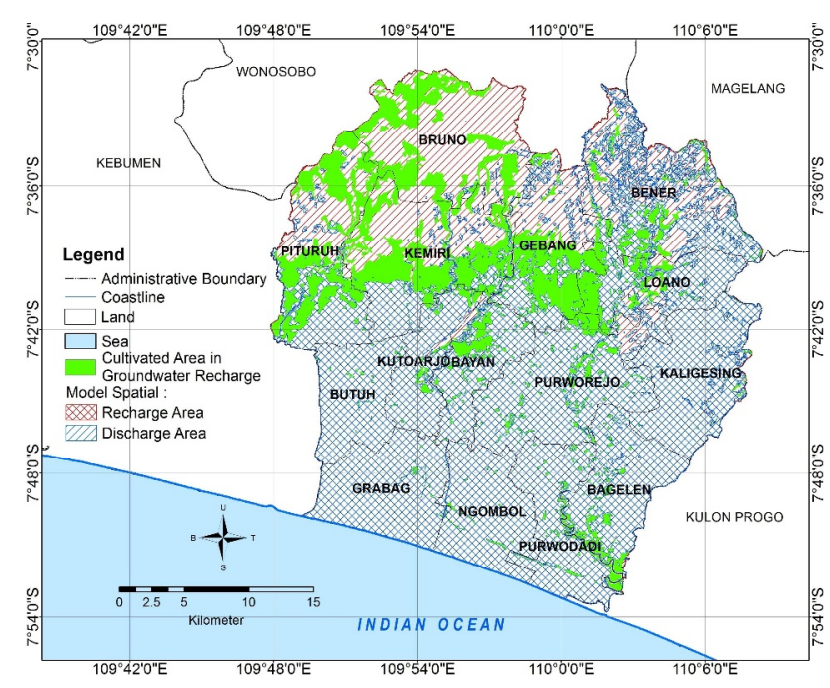

Fig. 3 Map of the suitability of the Recharge area with the Cultivation Area in Spatial Planning 


\section{Conclusion}

The recharge area is a protected area that should be used to protect other cultivated activities. Based on the spatial analysis of groundwater recharge area, there is a potential area of groundwater recharge area of 42,192.14 ha. Assessing the groundwater recharge area which is overlaying to the Spatial Planning map in Purworejo regency, there is still some land use that should be used for protected areas (as groundwater recharge) however it is utilized as the cultivation area. It should be concerned to the regional government in the revision of the spatial plan for the protected area (groundwater recharge) so that it can be the environmental carrying capacity of protected areas and cultivation areas.

\section{Acknowledgements}

The authors are thanks to Public Works and Spatial Planning Office and Environment Office of Purworejo regency, Central Java Province for their help in data and information. We would like to thank Dr. Maryono and anonymous reviewers for critical and constructive review of the manuscript.

\section{References}

1. Republik Indonesia. Undang-Undang Nomor 26 Tahun 2007 tentang Penataan Ruang. 2007;(1):240353.

2. Wibowo M. J. Tek.Ling P3TL-BPPT. 4.(1):8-13. (2003)

3. Asdak C. J. Tek.Ling P3TL-BPPT. 7.(1):16-25. (2006)

4. Yeh H, Cheng Y, Lin H, Lee C. Sustain Environ Res. 26(1):33-43. (2016)

5. Aryanto DE, Hardiman G. E3S Web of Conferences 31, 12002 (2018).

6. Baniya N. Dissertation. 2008:1-259.

7. Resubun, E., Tarore, R., Takumansang ED. Thesis. (26):174-182.7. (2014)
8. M. Nagarajan, S. Singh, J Indian Soc Remote Sens. 37(1):69-77. (2009)

9. T. N. Adji, \& S. P. Sejati, Arab J Geosci. 161-172. (2014)

10. IP. Senanayake, DMDOK. Dissanayake, BB. Mayadunna, WL. Weerasekera, Geosci Front. 7(1):115-124. (2016)

11. M. A. Manap, H. Nampak, B. Pradhan, S. Lee, , W. N. A. Sulaiman, M. F. Ramli, Arabian Journal of Geosciences, 7(2), 711-724. (2014)

12. A. Madani, B. Niyazi, Environ Earth Sci. 74(6):5129-5142. (2015)

13. SF. Elbeih, Ain Shams Eng J. 6(1):1-15. (2015)

14. SA. Ahmed, Egypt J Remote Sens Sp Sci. 19(2):223234. (2016)

15. NS. Magesh, N. Chandrasekar, JP. Soundranayagam, Geosci Front. 3(2):189-196. (2012)

16. Badan Pusat Statistik Kabupaten Purworejo. Kabupaten Purworejo dalam angka. 2017.

17. KEPUTUSAN PRESIDEN REPUBLIK INDONESIA NOMOR 26 TAHUN 2011 TENTANG PENETAPAN CEKUNGAN AIR TANAH. 1-16. (1999)

18. Danaryanto T., Setiadi H., Siagian Y. Kumpulan Pedoman Teknis Pengelolaan Air Tanah pada Cekungan Air Tanah (CAT). 2007. Badan Geologi. Bandung.

19. Putranto TT., Hidajat WK., Wardhani AK. J. Tataloka-Planologi UNDIP. 19(3):175-191.(2017).

20. Adibah, N., Kahar, S., Sasmito B. 2(2):141153.(2013)

21. Sigit AA.Forum Geografi. 25(1):27-40. (2011)

22. Yeh H, Cheng Y, Lin H, Lee C. Sustain Environ Res. 26(1):33-43. (2016).

23. Todd, D. K. and Mays, L. W. 2005. Groundwater Hydrology, 3rd Ed. John Willey and Sonc.inc: New York.

\footnotetext{
* Corresponding author: putranto@ft.undip.ac.id
} 